\title{
Availability of two species of fruits and their influence on the social structure of Tayassu pecari and Dicotyles tajacu
}

\author{
Marcos Briceño-Méndez ${ }^{*}$, Eduardo J. Naranjo² ${ }^{2}$ Mariana Altrichter ${ }^{3}$ and Salvador Mandujano ${ }^{4}$ \\ 1 Secretaria de Medio Ambiente y Recursos Naturales del Estado de Campeche, Patricio Trueba de Regil, Niebla Planta Alta. \\ Fracciorama 2000, s/n, CP. 24090, San Francisco de Campeche, Campeche, México. Email: marc12 87@hotmail.com (MBM) \\ ${ }^{2}$ El Colegio de la Frontera Sur. Carretera Panamericana y Periférico Sur s/n, San Cristóbal de Las Casas, Chiapas, México 29290. San \\ Cristóbal de Las Casas, Chiapas, México. E-mail: enaranjo@ecosur.mx (EJN) \\ ${ }^{3}$ Peccary Specialist Group, International Union for Conservation of Nature (IUCN), Prescott College, Arizona, USA. E-mail: \\ marianaalt@msn.com (MA). \\ ${ }^{4}$ Instituto de Ecología, A.C., Xalapa, Veracruz, México. E-mail: salvador.mandujano@inecol.mx (SM) \\ *Corresponding author
}

The white-lipped peccary (Tayassu peccari) and the collared peccary (Dicotyles tajacu) are social ungulates that contribute to tropical forest maintenance, molding the composition of tree species through herbivory and seed dispersal and predation. The fruits of zapote (Manilkara zapota) and ramon (Brosimum alicastrum) trees are important items in the diet of both peccary species. The objective of this study was to assess the relationship between the abundance of fruits of Manilkara zapota and Brosimum alicastrum and its relationship with the number of newborns in groups of both peccary species during the rainy and dry season in a tropical forest in the Yucatan Peninsula, Mexico. Peccary groups were monitored with ten camera trap stations and through direct observations during the dry season of 2014 (February-May) and the rainy season of 2015 (June - September). To estimate fruit availability, five transects ( $2 \mathrm{~km}$ long) were set at random in forested areas. Several 2-m ${ }^{2}$ tree plots were established in each transect to obtain a fruit abundance index. Peccary group size and number of newborns in each season were correlated with fruit abundance. In both species, group size was significantly larger in the dry vs. rainy season $(P<0.001)$. Offspring were proportionally more abundant during the dry season $(P<0.001)$. Fruits of $M$. zapota were more abundant in the dry season and reached the peak availability in May $(P<0.001)$. Fruits of $B$. alicastrum were more abundant in the rainy season, reaching the peak availability in September $(P<0.001)$. For both peccary species, the highest numbers of newborns in individual groups may be attributable, although not specifically, to the abundance of M. zapota fruits during the dry season. In this sense, the groups of both peccary species may depend on the seasonal availability of food of key species, such as the fruits of $M$. zapota during the dry season. Based on these results, preserving areas in good conservation status is deemed important, as well as reducing tree clearing of species such as zapote and ramon at the study site.

El pecarí de labios blancos (Tayassu pecari) y el pecarí de collar (Dicotyles tajacu) son especies de ungulados sociales que contribuyen en al mantenimiento y composición arbórea de los bosques del trópico a través de los procesos de herbivoría, dispersión y depredación de semillas. Los frutos del zapote (Manilkara zapota) y ramón (Brosimum alicastrum) son especies arbóreas importantes en la dieta de ambas especies. El objetivo de este estudio fue evaluar la relación entre la abundancia de frutos de Manilkara zapota y Brosimum alicastrum y su relación con el número de crías en grupos de pecarí de ambas especies durante la estación seca y húmeda de una selva tropical en la Península de Yucatán, México. Se realizó un monitoreo con 10 estaciones de cámaras trampa y observaciones directas de grupos de pecaríes durante la estación seca de 2014 (febrero-mayo) y la estación de lluvias de 2015 (Junio-Septiembre). Para estimar la disponibilidad de frutos, se recorrieron cinco transectos de $2 \mathrm{~km}$ de longitud establecidos al azar en la zona forestal. En cada uno de los transectos se establecieron 15 parcelas de $2 \mathrm{~m}^{2}$ para obtener un índice de abundancia de frutos. El tamaño de grupo y número de crías en ambas estaciones se correlacionó con la abundancia de frutos. En ambas especies el tamaño de grupos fue mayor significativamente en la estación seca que lluvias $(P<0.001)$. La proporción del número de crías fue mayor significativamente durante los meses de la estación seca $(P<0.001)$. Los frutos de $M$. zapota fueron también más abundantes en la época de secas alcanzado su mayor disponibilidad en mayo $(P<0.001)$. Los frutos de $B$. alicastrum fueron más abundantes en los meses de la estación lluviosa alcanzando su mayor disponibilidad en septiembre $(P<0.001)$. Para ambas especies de pecaríes, el mayor número de crías presentes en los grupos puede ser atribuible a la abundancia de frutos de $M$. zapota durante la estación seca. En este sentido, los grupos de ambas especies de pecaríes podrían llegar a depender de la disponibilidad de alimento estacional de especies clave como los frutos de M. zapota durante la estación seca. Con base a estos resultados se considera importante conservar áreas en buen estado de conservación, y reducir la tala de especies como el zapote y el ramón en el sitio de estudio.

Key words: Brosimum alicastrum; Calakmul; fruit index availability; Manilkara zapota; ramon; newborns; peccary; zapote.

C 2017 Asociación Mexicana de Mastozoología, www.mastozoologiamexicana.org

Introduction

Frugivorous or omnivorous mammals are a key component in tropical forest ecosystems, since they serve as seed dispersers or predators (O' Farrill et al. 2006, 2011; Peres et al. 2016). This contributes to the regeneration of forests, by structuring their composition (Peres et al. 2016). However, the reduction of tropical forests through changes in land use affects the diversity and availability of fruits and pro- longs the natural periods of scarcity (Tabarelli et al. 2004; Keuroghlian and Eaton 2008). As a result, some mammal species migrate to other areas in search of fruits, while others are able to make adjustments to their diets (Altricher et al. 2001; Keuroghlian 2003; Keuroghlian and Eaton 2008). In peccary species (Tayassu pecari and Dicotyles tajacu), it has been pointed out that the breeding, gestation and birth periods are related to the nutritional quality of food 
resources and the primary productivity of key fruit species available in the environment (Altricher et al. 2001; Keuroghlian et al. 2004; López et al. 2006).

The white-lipped peccary (T. pecari) and the collared peccary ( $D$. tajacu), belonging to the Family Tayassuidae, are important social ungulate species in tropical ecosystems. Both species contribute to the maintenance and composition of trees in forests through herbivory and seed dispersal and predation (Bodmer 1991; March 1993; Beck 2005, 2006; Keuroghlian and Eaton 2009; Beck et al. 2010). Peccaries are an essential food resource for the inhabitants of rural and indigenous communities throughout their distribution range (Weber 2000; Altrichter and Boaglio 2004; Desbiez et al. 2009; Reyna-Hurtado et al. 2010; Briceño-Méndez et al. 2011; Keuroghlian et al. 2013; Naranjo et al. 2015). Wild populations of both species are currently under an intense pressure by hunting and loss of habitat (Reyna-Hurtado 2009; Góngora et al. 2011; Altrichter et al. 2012; Keuroghlian et al. 2013; Naranjo et al. 2015; Briceño-Méndez et al. 2016).

The Calakmul region, in the state of Campeche, is one of the main remnants of tropical forest in Mexico and includes the Calakmul Biosphere Reserve (RBC; 7,231 km²). Various activities such as the production of charcoal and the use of natural resources have led the accelerated deforestation and fragmentation of the primary vegetation, in addition to poaching of wild species. A site adjacent to this reserve is the ejido Nuevo Becal, stretching across $520 \mathrm{~km}^{2}$, where the loss of habitat and poaching of wild species prevail (Briceño-Méndez et al. 2016). The forests of the Calakmul region include two tree species that are key in the diet of peccaries (Reyna-Hurtado 2007; Perez-Cortez and ReynaHurtado 2008): the ramon, Brosimum alicastrum, and the zapote, Manilkara zapota. These species account for 57.10 $\%$ of the total species producing fruits consumed by peccaries on the ground (Briceño-Méndez et al. 2014). Given the importance of their fruits as a source of food, these species have also been described as part of the diet of primates such as the spider monkey, Ateles geoffroyi, and the howler monkey, Alouatta pigra (Hernández-Sarabia 2013), as well as of other ungulates such as the tapir, Tapirus bairdii ( $\underline{\mathrm{O}}^{\prime}$ Farrill et al. 2006, 2011) and the temazates deer, Mazama temama and M. pandora (Weber 2008; González-Zamora et al. 2009).

An investigation conducted in RBC has revealed that the availability of ramon is related to the surface area used by T. pecari (Reyna-Hurtado 2007). However, it is unknown whether the proportion of newborns in groups of peccaries varies according to the season. This could be related to the availability of M. zapota and B. alicastrum fruits, documented as essential seasonal food items in the peccary diet (Reyna-Hurtado 2007, Perez-Cortez and Reyna-Hurtado 2008). Unveiling the relationship between the availability of key fruit species such as ramón and zapote and the composition in the social structure of peccaries is essential for management and conservation plans. The objectives of this study were two. Quantify the seasonal availability and variations of M. zapota and B. alicastrum fruits in ejido Nuevo Becal. Evaluate the social structure of T. pecari and D. tajacu. Specifically, it was assessed whether there are fluctuations in the number of newborns of the two peccary species according to the rainy and dry seasons matching the availability of M. zapota and B. alicastrum fruits.

\section{Materials and Methods}

Area of study. The site is located in the southeastern portion of the Calakmul region, at ejido Nuevo Becal $\left(18.6920^{\circ} \mathrm{N}\right.$, $-89.2511^{\circ} \mathrm{W} ; 20.9450^{\circ} \mathrm{N},-89.6433^{\circ} \mathrm{N} ; 21.2811^{\circ} \mathrm{N},-89.6650^{\circ}$ $\mathrm{W} ; 21.0161^{\circ} \mathrm{N},-89.8772^{\circ} \mathrm{W}$ ), in the municipality of Calakmul, Campeche, Mexico. This area is adjacent to RBC, a protected area of tropical forest in Mexico with an extension of $7,231 \mathrm{~km}^{2}$ (Figure 1).

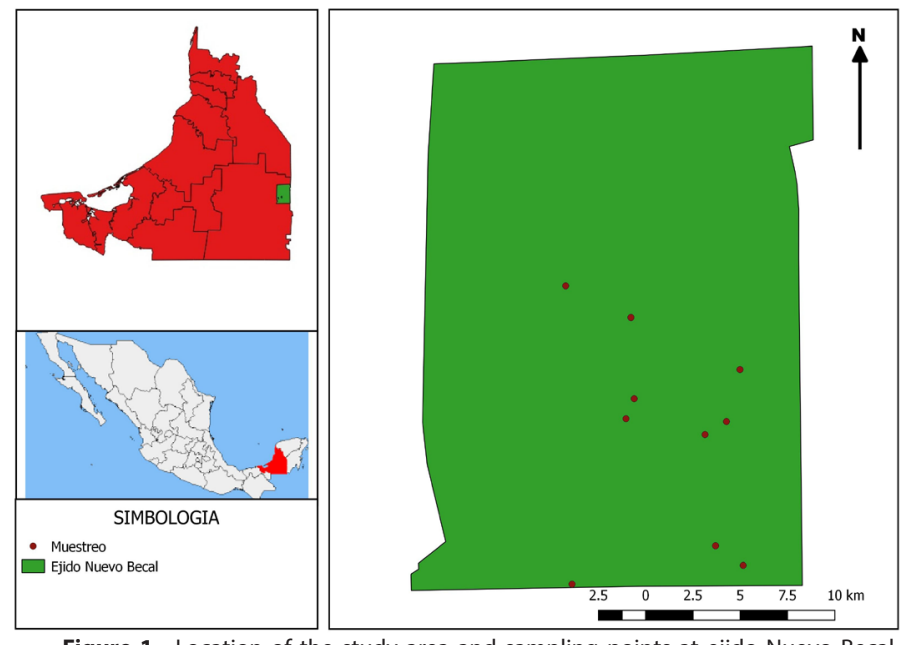

Figure 1. Location of the study area and sampling points at ejido Nuevo Becal Calakmul, Campeche Mexico.

The ejido comprises an area of $520 \mathrm{~km}^{2}$. The types of vegetation include subdeciduous forest, floodplain forests, dry forests, and secondary vegetation (Pennington and Sarukhan 1998). Elevation ranges between 100 to 380 masl. The predominant climate is warm sub-humid with summer rainfall and with less than $60 \mathrm{~mm}$ of precipitation in the driest month; the mean annual temperature is $25^{\circ} \mathrm{C}$ (García-Gil 2003).

Social structure. During the 2014 dry season (FebruaryMay) and the 2015 rainy season (June-September) peccary groups were monitored in 10 camera-trap stations (Reconyx PC800 Hyperfire Professional IRTM y PC600 Hyperfire Pro White FlashTM; Reconyx, Inc., Holmen, Wisconsin, USA) on a permanent basis in sites near water bodies, roads and trails selected at random in the ejido section covered by natural vegetation. Camera traps were placed at a height not exceeding $50 \mathrm{~cm}$ from ground level and with a separation of $1.5 \mathrm{~km}$, covering an area of approximately $112 \mathrm{~km}^{2}$ delimited by the external location of traps (Figure 1). The period of photographic records was set to operate 24 hours with trigger intervals of one second. This interval allows counting all individuals passing in a line or grouped (Maffei et al. 2002; Figure 2). Records were considered independent after 24 hours between one record and another, or when 
more than one individual appeared in the photograph. The position of each station was georeferenced with a Garmin $62 s^{\circledast}$ GPS. For each picture obtained, the time and date was recorded (Lira Torres et al. 2014). The age structure of each group was examined and evaluated by obtaining the individuals into three categories, adults, juveniles, and young, according to size and pelage coloration; then, the percentage of each category was calculated (Reyna-Hurtado et al. 2010). The average number of hatchlings was estimated and counted during the month of birth, either in the February-May dry season or in the June-September rainy season (Figure 2).

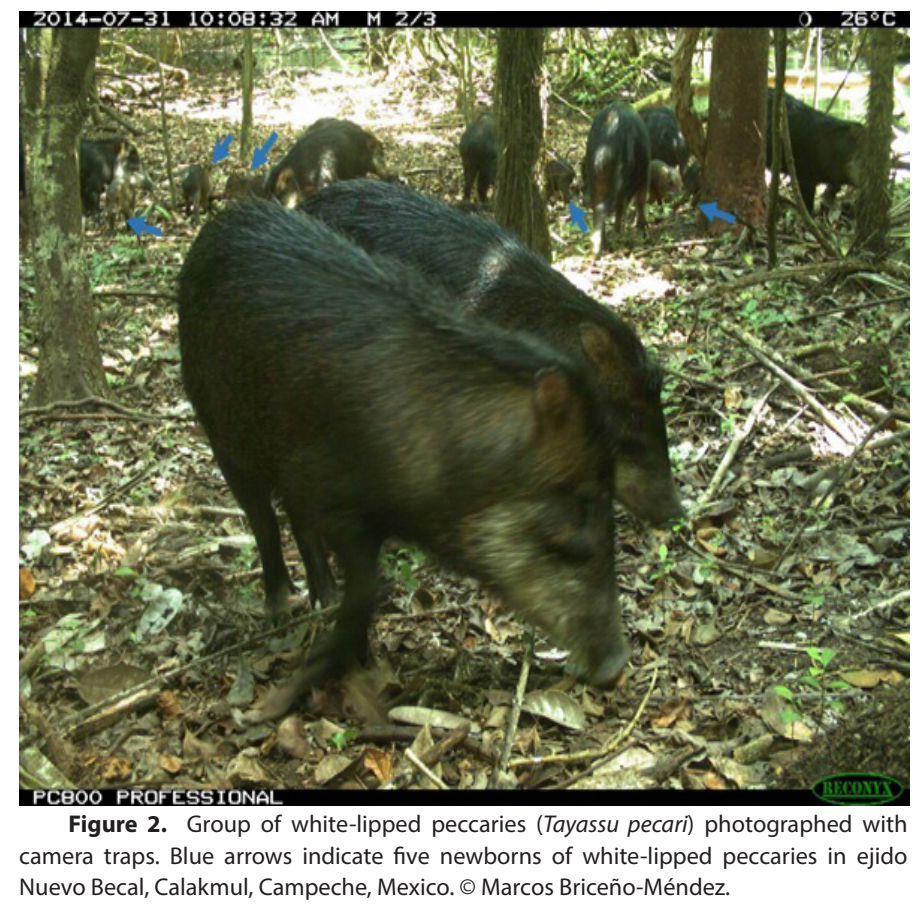

Fruit Availability. To estimate fruit abundance, five 2 $\mathrm{km}$-long transects were established, which were determined randomly in forested areas, avoiding a radius of at least $7 \mathrm{~km}$ from the village. Transects were visited once a month in order to derive a fruit abundance index (Altrichter et al. 2001). The method consists in finding a fruit on the ground, then locating the source tree where the fruit came from, provided it is located at a perpendicular distance not exceeding $5 \mathrm{~m}$ from the center line of the transect. Once the source tree was located, all the fruits found within a quadrat of $2 \mathrm{~m}^{2}$ under the canopy were recorded.

Data Analysis. To evaluate the differences in the size of the groups of both species between the dry and rainy seasons, and the proportion newborns, Mann-Whitney tests were conducted. We used the availability index of each fruit species and the monthly variation was evaluated using a Pearson's Chi $^{2}$ non-parametric test. In all cases, statistical tests considered a significance level of $P<0.05$. The variables analyzed were the proportion of newborns per group, species, fruit availability index, dry season and rainy season. A simple correlation analysis was conducted between fruit availability index values and number of newborns. The statistical analyzes were performed in SPSS v. 17.0.

\section{Results}

The sampling effort was 2,420 trap-nights (302.5 trap-nights per month) and a total of 86 records of Tayassu pecari were obtained, resulting in a total of 1,026 individuals counted. For Dicotyles tajacu, 76 records were obtained, leading to a total of 33 individuals counted.

A higher number of groups and individuals of both species were observed in the dry season (T. pecari 53.8; $D$. tajacu 46.2 ) versus the rainy season (T. Pecari 33.1; D. tajacu 30.1). Similarly, the average size (mean \pm SD) of groups for both species was significantly higher in the dry season ( $T$. pecari $23 \pm 5.3, n=53 ; D$. tajacu $4.9 \pm 2.6, n=46 ; U=0.01$ ).

Social structure. The age structure of T. pecari in the dry season was determined based on 886 individuals, with the following proportions: adults, $76.3 \%$; sub-adults, $9.4 \%$; and newborns $14.3 \%$. In the rainy season, the age structure on the basis of 140 adult individuals was $66.6 \%$, sub-adults $26.2 \%$ and $7.2 \%$ newborns. The age structure of $D$. tajacu in the dry season $(n=46)$ was: adults, $76.0 \%$; sub-adults, $7.7 \%$; and newborns, $16.3 \%$; the percentages of these age classes for the rainy season $(n=17)$ are $93.0 \%, 6.0 \%$ and 1.0 $\%$, respectively. In both species, the proportion of offspring was significantly higher during the months of the dry season T. pecari $\left(X^{2}=27.14\right.$, d. f. $\left.=7, P<0.001\right)$ and D. tajacu $\left(X^{2}\right.$ $=34.0$, d. f. $=5, P<0.001$, Figure 3,4$)$.

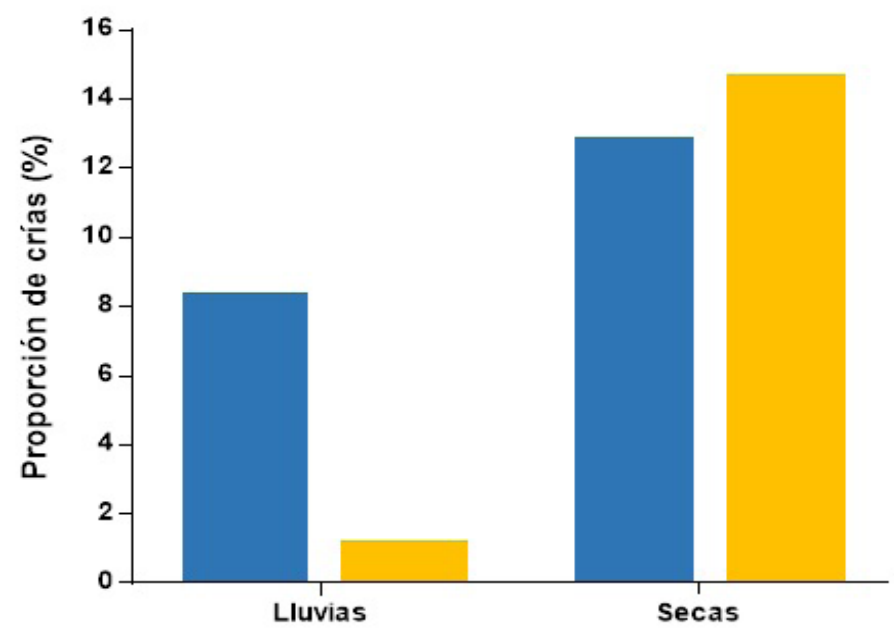

Figure 3. Proportion of the number of newborns in groups of white-lipped peccary (Tayassu pecari) (blue bars), and collared peccary (Dicotyles tajacu) (yellow bars) recorded during the 2014 dry season and 2015 rainy season in ejido Nuevo Becal, Calakmul, Campeche, Mexico.

Fruit Availability. The walkthrough of $80 \mathrm{~km}$ of transects $(n=5)$ in 15 plots per season (dry and rainy seasons) yielded a total of 329 fruits of B. alicastrum and 267 of M. zapota. The fruit availability index for ramon was variable, peaking in September $\left(X^{2}=39.00\right.$, d. f. $=3, P<0.001$, Figure 4). The availability of $M$. zapota fruits was significantly higher in the dry season and varied throughout this season, reaching its peak availability in May $\left(X^{2}=33.14\right.$, d. $f .=7, P<0.001$, Figure 4). The proportion of offspring in both peccary species was significantly correlated with the availability of M. zapota fruits during the dry season (T. pecari, $\mathrm{r}^{2}=0.43 ; D$. tajacu, $\mathrm{r}^{2}$ $=0.46$ ). 


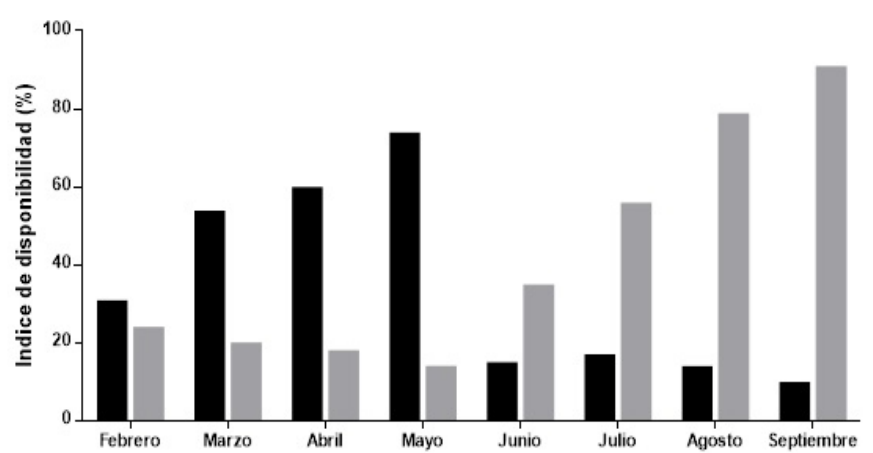

Figure 4. Availability of fruits of zapote Manilkara zapota (black bars) and ramon Brosimun alicastrum (gray bars) during the dry season (Feb-May 2014) and rainy season (June-Sept 2015) in ejido Nuevo Becal, Calakmul, Campeche, Mexico.

\section{Discussion and Conclusions}

Social Structure and Fruit Availability. In both species, the social structure within groups showed a higher proportion of adults. This is consistent with the findings reported in the Calakmul Biosphere Reserve (Reyna-Hurtado et al. 2010), in areas subjected to hunting pressure in ejido Nuevo Becal for the white-lipped peccary (Briceño-Méndez et al. 2016), and for the collared peccary in the Chimalapas, Oaxaca (Pérez Irineo and Santos Moreno 2016).

The proportion of offspring was higher in the dry season than in the rainy season for both species; this is consistent with the findings reported for white-lipped peccaries in the Calakmul Biosphere Reserve (Reyna-Hurtado et al. 2010). However, for the collared peccary these findings are contrary to those reported in French Guiana, where the proportion of offspring is higher in the rainy season (Henry 1994).

Although there are no data on the nutritional value of the fruit species for peccaries, it has been reported that both ramon and zapote play a key role in the seasonal diet of both species (Perez-Cortez and Reyna-Hurtado 2008). This fact may explain the relationship between the presence of a higher number of offspring of both species during the dry season and the fruit abundance index for zapote fruits. Two plant species (Ficus spp. and Licania operculipetata) have been mentoned as fructifying during periods of shortage of other food items, and are related to the breeding season and number of offspring, which affects the size and composition of groups in both peccary species, although not necessarily being the factor that could be driving the increase in group size in both species (Altricher et al. 2001; Keuroghlian 2004). Another possible explanation in relation to the number of offspring during the greater availability of fruits, is that these may be providing postpartum mothers nutrient needs for young infants (Lopez et al. 2006).

The fruits of Pouteria campechiana, Ampelocera hottlei, Cratavea tapia, Byrsonima crassifolia, Citrullus vulgaris, Talisia olivaeformis and Metopium brownei are identified as potential food items for peccaries in the region, being a supplement to their diet (Perez-Cortez and Reyna-Hurtado 2008). The production of these fruits is variable; they are usually available for very short periods of time (ReynaHurtado 2007; Briceño-Méndez et al. 2014), contrary to the zapote and ramon fruits, which are available throught a season. For example, zapote can reach peak fruit availability in the dry season during May, while ramon reaches its highest fruit abundance index values in the rainy season (Reyna-Hurtado 2007; Briceño-Méndez et al. 2014).

Both peccary species are benefited by the availability and search for these important dietary resources in heterogeneous environments during well-marked seasons of the year in the study site. In addition, peccaries can consume a wide variety of food types available in the landscape, and even modify their diet (Keuroghlian 2004; Beck 2005; Keuroghlian and Eaton 2008; Fernandes et al. 2013).

Our results reveal the relationship between the primary productivity of fruit species and the size and social composition in groups of both peccary species in the tropics (Altrichter et al. 2001). There are other factors related to group composition and size; for example, it has been documented that in the rainy season white-lipped peccaries consume small amounts of animal food items, including invertebrates and some fish species (Fernandes et al. 2013; Reyna-Hurtado 2007). Water availability, the state of conservation of the habitat and the hunting pressure have been considered as factors that strongly influence group size in peccaries inhabiting the Calakmul region (ReynaHurtado et al. 2015).

Conservation Perspectives. An important factor for the conservation of peccaries is the reduction and/or control of zapote tree logging, which is an important resource in the study site. The plant species consumed by peccaries are also relevant for other endangered species such as the spider monkey (Ateles geoffroyi), howler monkey (Alouatta pigra), tapir (Tapirus bairdii), temazate deer (Mazama temama and Mazama pandora), all of which depend to a large extent on these fruit species to supplement their diet ( $\mathrm{O}^{\prime}$ Farrill et al. 2006, 2011; Weber 2008; González-Zamora et al. 2009).

The ejido Nuevo Becal is home to endangered species and includes habitats in good state of conservation (Briceño Méndez et al. 2017). However, human activities such as hunting and loss of habitat still prevail (Escamilla et al. 2000; Santos Fita et al. 2012; Briceño-Méndez et al. 2014). Therefore, it is imperative to introduce feasible subsistence strategies to the local community (Montiel et al. 1999), particularly for being a rural community that is connected to the Calakmul Biosphere Reserve.

\section{Acknowledgments}

This study was carried out thanks to the support of the authorities of the Calakmul Biosphere Reserve, the staff of the Comisión Nacional de Áreas Nacionales Protegidas (National Commission of Protected Natural Areas, CONANP), who collaborated in various logistical support tasks. The grant \# 248308 was granted to the first author by the Consejo Nacional de Ciencia y Tecnología. To R. Reyna Hurtado for the financial support granted through the Basic Science Project \# 182386 (CONACyT). To C. Chapman for his 
support with camera traps through the McGill University. To Colegio de la Frontera Sur, Campeche. Thanks also to the inhabitants of Nuevo Becal, Campeche, in particular, to N. Arias Domínguez and H. Arias Dominguez. To E. Sandoval, R. de la Cerda, M. Sanvicente, G. Castillo, I. Chi, L. Ramirez, K. Sanchez , A. Matos and R. Heredia for their assistance in data collection. Two anonymous reviewers provided valuable comments on a previous version of this manuscript. María Elena Sánchez-Salazar translated the manuscript into English.

\section{Literatura citada}

Altrichter, M., E. Carrillo, J. Saenz, and K. Fuller. 2001. Whitelipped peccary (Tayassu pecari, Artiodactyla: Tayassuidae) diet and fruit availability in a Costa Rican rain forest. Revista de Biología Tropical 49:1183-1192.

Altrichter, M., AND G. L. Boaglio. 2004. Distribution and relative abundance of peccaries in the Argentine Chaco: associations with human factors. Biological Conservation 116:217-225.

Altrichter, M., A. Taber, H. Beck, R. Reyna-Hurtado, L. Lizarraga, A. KEUROGHLIAN, AND E. W. SANDERSON. 2012. Range-wide declines of a key Neotropical ecosystem architect, the Near Threatened white-lipped peccary Tayassu pecari. Oryx 46:87-98.

BECK, H. P. 2005. Seed predation and dispersal by pecaries thoughout the Neotropics and its consequence: a review and synthesis. Pp.77-115, in Seed fate: predation, dispersal and seedling establishment (Forget, P. M., P. E. Hulme, and S. B. Vander Wall, eds.). CABI Publishing. Wallingford, United Kingdom.

BECK, H. P. 2006. A review of peccary-palm interactions and their ecological ramifications across the Neotropics. Journal of Mammalogy 87:519-530.

BECK, H., P.THEBPANYA, AND M. FILIAGGI. 2010. Do Neotropical peccary species (Tayassuidae) function as ecosystem engineers for anurans? Journal Tropical Ecology 26: 407-414.

Briceño-Méndez, M. A., R. Montes, W. Aguilar, and A. Pool. 2011. Cacería del pecarí de collar (Pecari tajacu) (Artiodactyla: Tayassuidae) en Tzucacab, Yucatán, México. Revista Mexicana de Mastozoología 15:8-18.

Briceño- Méndez, M. A., R. Reyna-Hurtado, S. Calme, and G. GarcíaGIL. 2014. Preferencias de hábitat y abundancia relativa de Tayassu pecari en un área con cacería en la región de Calakmul, Campeche, México. Revista Mexicana de Biodiversidad 85:242-250.

Briceño-Méndez, E. J. Naranjo, S. Mandujano, M. Altrichter, and R. Reyna-HuRtado. 2016. Responses of two sympatric species of peccaries (Tayassu pecari and Pecari tajacu) to hunting in Calakmul, Mexico. Tropical Conservation Science 9:1-11.

Briceño-Méndez, M., E. J. Naranjo, G. Pérez-Irineo, Y. Contreras-Perera, E. SANDoval-Serés, AND M. G. Hidalgo Mihart. 2017. Richness and trophic guilds of carnivorous mammals in ejido Nuevo Becal, Calakmul, Campeche, Mexico. Therya 8:145-150

Bodmer, R. E. 1991. Strategies of seed dispersal and seed predation in Amazonian ungulates. Biotropica 23:255-261.

Desbiez, A. L. J., Santos, S. A., A. Keuroghlian, and R. E. Bodmer. 2009. Niche partitioning among white-lipped peccaries (Tayassu pecari), collared peccaries (Pecari tajacu), and feral pigs (Susscrofa). Journal of Mammalogy 90:119-128.
Escamilla, A., M. Sanvicente, M. Sosa, and C. Galindo. 2000. Habitat mosaic, wildlife availability, and hunting in the tropical forest of Calakmul, México. Conservation Biology 14:1592-1601.

Fernandes, D. A., Keuroghlian, D. P., Eaton, And A. Desbiez. 2013. When there are no fruits for white-lipped peccaries, how about Sushi? Suiform Soundings 12:51-54

GARCíA-GIL, G. 2003. Colonización humana reciente y formación del paisaje agrario en la Reserva de la Biosfera de Calakmul, Campeche, México. Tesis de doctorado. Facultad de filosofía y letras. Universidad Nacional Autónoma de México. Ciudad de México, México.

Golden, C. D., M. Bonds, J. S. Brashares, B. J. Rasolofoniaina, and C. KREMEN. 2014. Economic valuation of subsistence harvest of wildlife in Madagascar. Conservation Biology 28: 234-243.

Góngora, J., R. Reyna-Hurtado, H. Beck, A. Taber, M. Altrichter, and A. Keuroghlian. 2011. Pecari tajacu. La lista Roja de la UICN de especies amenazadas. Versión 2014.3< www.iucnredlist.org $>$. Consultado el 29 de diciembre de 2014.

González-Zamora A., V. Arroyo-Rodriguez, and O. M. Chaves. 2009. Diet of spider monkeys (Ateles geoffroyi) in Mesoamerica: current knowledge and future directions. American Journal of Primatology 71:8-20.

HenRY, O. 1994. Saisons de reproduction chez tres Rongeurs et un Ariodactyle en Guyane FrancËaise, en fonction des facteurs du milieu et de I'alimentation. Mammalia 58:183200.

Hernández Sarabia, R. U. 2013. Estrategias de desplazamiento de Ateles geoffroyi yucatanensis y Alouatta pigra en la búsqueda de recursos tróficos durante la temporada seca y húmeda en la Reserva de la Biosfera, Calakmul, Campeche, México. Tesis de maestría. Universidad Veracruzana. Jalapa, México.

KEUROGHLIAN, A. 2003. The response of peccaries to seasonal fluctuations in an isolated patch of tropical forest. Ph.D. Dissertation. University of Nevada, Reno, Nevada.

Keuroghlian, A., D. P. Eaton, and W. S. Longland. 2004. Area use by white lipped and collared peccaries (Tayassu pecari and Tayassu tajacu) in a tropical forest fragment. Biological Conservation 120:411-425.

KeUroghlian, A., and D. P. Eaton. 2008. Fruit availability and peccary frugivory in an isolated Atlantic forest fragment: effects on peccary ranging behavior and habitat use. Biotropica 40:62-70.

Keuroghlian, A., AND D. P. Eaton. 2009. Removal of palm fruits and ecosystem engineering in palm stands by white-lipped peccaries (Tayassu pecari) and other frugivores in an isolated Atlantic Forest fragment. Biodiversity and Conservation 18:17-33.

Keuroghlian A., A. Desbiez, R. Reyna-Hurtado, M. Altrichter, B. Beck, A. TABER, AND J. M. V. Fragoso. 2013. Tayassu pecari en IUCN 2013. IUCN Red List of Threatened Species. Version 2013.2. <www.iucnredlist.org>. Downloaded on 18 Noviembre 2015. Lira-Torres, I., M. Briones-Salas, and G. Sanchéz-Rojas. 2014. Abundancia relativa, estructura poblacional, preferencia de hábitat y patrones de actividad del tapir centroamericano Tapirus bairdii (Perissodactyla: Tapiridae), en la Selva de Los Chimalapas, Oaxaca, México. Revista de Biología Tropical 62:1407-1419.

López, M., M. Altrichter, J. SAENZ, and E. EDUARTE. 2006. Valor Nutricional de los Alimentos de Tayassu pecari (Atiodactyla: 
Tayassuidae) en el Parque Nacional Corcovado, Costa Rica. Revista de Biología Tropical 54:687-700.

Maffel, I., E. Cuellar, AND J. Noss. 2002. Uso de trampas cámara para la evaluación de mamíferos en el Ecotono ChacoChiquitanía. Revisa de Biología Tropical 11:55-65.

Montiel S, L., Arias, And F. Dickinson. 1999. La cacería tradicional en el norte de Yucatán: Una práctica comunitaria. Revista de Geografía Agrícola 29:43-52.

MARCH, I. J. 1993. The white-lipped peccary (Tayassu pecari). Pp. 13-22 in Pigs, Peccaries and Hippos (Oliver, W. L. R., ed.). IUCN. Gland, Suiza.

Naranjo, E. J., S. A. Amador-Alcalá, F. A. Falconi-Briones, and R. ReynaHuRTADO. 2015. Distribución, abundancia y amenazas a las poblaciones de tapir centroamericano (Tapirus bairdii) y pecarí de labios blancos (Tayassu pecari) en México. Therya 6:227-249.

O'Farrill, G., S. Calme, and A. GonzÁlez. 2006. Manilkara zapota: A new record of a species dispersed by tapirs. Tapir Conservation 15:32-35.

O'Farrill, G., A. C. Chapman, and A. González. 2011. Origin and deposition sites influence seed germination and seedling survival of Manilkara zapota: implications for long-distance, animal-mediated seed dispersal. Seed Science Research 21:305-313.

Peres, C. A., T. Emilio, J. Schietti, S. J. M. Desmoulière, and T. LeVi. 2016. Dispersal limitation induces long-term biomass collapse in overhunted Amazonian forests. Proceedings of the National Academy of Sciences of the United States of America 113:892-897.

Pérez-Cortez, S., and R. Reyna-Hurtado. 2008. La dieta de los pecaríes (Pecari tajacu y Tayassu pecari) en la región de Calakmul, Campeche, México. Revista Mexicana de Mastozoología 12:17-42.

Pennington, T. and J. Sarukhán. 1998. Árboles Tropicales de México. UNAM-Fondo de Cultura Económica. Ciudad de México, México.

Pérez-Irineo, G., and A. Santos-Moreno. 2016. Abundance, herd size, activity pattern and occupancy of ungulates in Southeastern Mexico. Animal Biology 66:97-109.

Reyna-Hurtado, R. 2007. Social ecology of the white-lipped peccary (Tayassu pecari) in Calakmul forest, Campeche, Mexico. (Tesis de doctorado). University of Florida. Gainesville, U. S. A.

Reyna-Hurtado, R. 2009. Conservation status of the whitelipped peccary (Tayassu pecari) outside the Calakmul Biosphere Reserve in Campeche, Mexico: a synthesis. Tropical Conservation Science 2:159-172.

Reyna-Hurtado, R., E. Naranjo, C. Chapman, and G. Tanner. 2010. Hunting patterns, population density, group size, and conservation of the white-lipped peccary (Tayassu pecari) in the Calakmul Region of Mexico. Oryx. 44:88-96.

Reyna-Hurtado, R., H. Beck, M. Altrichter, C. Chapman, R. B. Tyler, A. Keuroghlian, L. Arnaud, Desbiez, J. F. Moreira-Ramirez, G. O'farrill, J. M. Fragoso, and E. J. Naranjo. 2015. What ecological and anthropogenic factors affect group size in white-lipped peccaries (Tayassu pecari)? Biotropica 48:246-254

Santos-Fita. D., E. J. Naranjo, and R. Salazar. 2012. Wildlife uses and hunting patterns in rural communities of the Yucatan Peninsula, Mexico. Journal of Ethnobiology and Ethnomedicine 8:38.
Tabarelli, M., M. J. C. Silva, and C. Gascon. 2004. Forest fragmentation, synergisms and the impoverishment of Neotropical forests. Biodiversity and Conservation 13:14191425.

WEBER, M. 2000. Effects of hunting on tropical deer populations in southeastern México. Tesis de maestría. Royal Veterinary College. University of London. Londres, Reino Unido.

WEBER. M. 2008. Un especialista, un generalista y un oportunista: uso de tipos de vegetación por tres especies de venados en Calakmul, Campeche. En Lorenzo, C., E. Espinoza y J. Ortega (eds.). 2008. Avances en el Estudio de los Mamíferos de México. Publicaciones Especiales, Vol. II, Asociación Mexicana de Mastozoología, A. C. Ciudad de México, México.

Associated editor: Rafael Reyna

Submitted: October 5, 2016; Reviewed: November 11, 2016;

Accepted: June 14, 2017; Published on line: July 7, 2017. 